\title{
NEUROCYSTICERCOSIS
}

\section{DETECTION OF IgG, IgA AND IgE ANTIBODIES IN CEREBROSPINAL FLUID, SERUM AND SALIVA SAMPLES BY ELISA WITH TAENIA SOLIUM AND TAENIA CRASSICEPS ANTIGENS}

\author{
EDNEIA CASAGRANDA BUENO*, ADELAIDE JOSÉ VAZ**, \\ LUIS DOS RAMOS MACHADO***, JOSÉ ANTONIO LIVRAMENTO****
}

\begin{abstract}
We assayed samples of cerebrospinal fluid (CSF), serum and saliva from patients with neurocysticercoses, control group and individuals with other parasitoses, by ELISA with Taenia crassiceps vesicular fluid antigen (Tcra) and Taenia solium total antigen (Tso) for the detection of antibodies. The sensitivity for IgG-Tcra was $100 \%$ for CSF and serum, and $32.0 \%$ for saliva; and for IgG-Tso $100 \%$ for CSF, $80.0 \%$ for serum and $24 . \%$ for saliva. Specificity was $100 \%$ for CSF and $80.0 \%$ for serum with both antigens, and $100 \%$ for saliva with Tcra and $87.5 \%$ with Tso. The sensitivity and specificity for IgA-Tcra was, respectively, $40.0 \%$ and $100 \%$ for CSF, $36.0 \%$ and $97.1 \%$ for serum, and $4.0 \%$ and $90.0 \%$ for saliva. IgE detection showed $24.0 \%$ sensitivity and $97.1 \%$ specificity for serum, with no detection in CSF samples. The search for antibodies revealed the presence of $\operatorname{IgG}>\mathrm{IgA}>\mathrm{IgE}$ in CSF, serum and saliva samples, with IgG being present in all phases of the disease, while $\operatorname{IgA} / \operatorname{IgE}$ were more frequent in the inactive form.
\end{abstract}

KEY WORDS: cysticercosis, central nervous system, humoral immune response, $\operatorname{IgG}, \operatorname{IgE}, \operatorname{IgA}, T$. crassiceps.

\section{Neurocisticercose: detecção de anticorpos IgG, IgA e IgE em amostras de líquido cefalorraquidiano, soro e saliva por ELISA com antígenos de Taenia solium e Taenia crassiceps}

RESUMO - Analisamos amostras de líquido cefalorraquidiano (LCR), soro e saliva de pacientes com neurocisticercose, grupo de controle e indivíduos com outras parasitoses, por ELISA com antígenos de líquido vesicular de T. crassiceps (Tcra) e salino total de T. solium (Tso) para a pesquisa de anticorpos. A sensibilidade para IgG-Tcra foi $100 \%$ para LCR e soro e $32,0 \%$ para saliva, e para IgG-Tso $100 \%$ para LCR, $80,0 \%$ para soro e $24,0 \%$ para saliva. A especificidade foi de $100 \%$ para CSF e $80,0 \%$ para soro com ambos os antígenos, e $100 \%$ para saliva com Tcra e $87,5 \%$ com Tso. A sensibilidade e especificidade para IgA-Tcra foi, respectivamente: $40,0 \%$ e $100 \%$ para LCR, $36,0 \%$ e $97,1 \%$ para soro, e $4,0 \%$ e $90,0 \%$ para saliva. A pesquisa de IgE mostrou $24,0 \%$ de sensibilidade e $97,1 \%$ de especificidade para soro, sem detecção nas amostras de LCR. A pesquisa de anticorpos revelou a presença de $\mathrm{IgG}>\mathrm{IgA}>\mathrm{IgE}$ no LCR, soro e saliva, com presença de $\operatorname{IgG}$ em todas as fases evolutivas da doença, enquanto que $\operatorname{IgA} / \operatorname{IgE}$ foram mais frequentes na forma inativa.

PALAVRAS-CHAVE: cisticercose, sistema nervoso central, resposta imune humoral, IgG, IgE, IgA, $T$. crassiceps.

*Post-Graduation Student of the Faculty of Pharmaceutical Sciences (FPS) University of São Paulo (USP), São Paulo, Brazil; **PhD, FPS, USP; ***MD, PhD Faculty of Medicine (FM), USP; ****MD, PhD Associated Docent FM, USP. Part of this work was presented as Master's Dissertation of E. C. Bueno (USP, 1999). Financial support: FAPESP (96-7679-1). E. C. Bueno had a fellowship from CAPES. Aceite: 19outubro-1999.

Dra. Ednéia Casagranda Bueno - Av. Prof. Lineu Prestes 580 bloco 17 - Lab. Imunologia Clínica, Faculdade de Ciências Farmacêuticas USP - 05508-900, São Paulo SP - Brasil. E-mail: ecbueno@usp.br 
Neurocysticercosis (NC), the presence of Taenia solium metacestodes in tissues, is the most frequent and severe parasitic infection of the central nervous system. Its distribution is universal, being frequent in developing countries in Latin America, Africa, Asia and India ${ }^{1-5}$, and with cases reported in the United States due to the immigration of individuals coming from endemic areas ${ }^{6}$.

The diagnosis of NC is based on clinical, epidemiologic and laboratory approaches (neuroimaging and immunological methods). Since clinical diagnosis is hindered by the nonspecific and polymorphic symptomatology of $\mathrm{NC}$, the detection of anti-T. solium antibodies in the cerebrospinal fluid (CSF) constitutes an important diagnostic element. One of the difficulties in such studies is obtaining parasites from the model of natural infection in swine. Taenia crassiceps metacestodes, found in rodents, have been described in natural and experimental infections, and have been used as an alternative source of antigen in immunological tests for $\mathrm{NC}^{2,7-11}$.

Most of the antibodies found in CSF are intrathecally synthesized, with a smaller proportion coming from peripheral blood by blood-brain barrier rupture ${ }^{12}$. Several authors have detected IgG antibodies in CSF and/or serum from patients with $\mathrm{NC}$, especially when the parasite is in the phase of degeneration and there is an increased immune-inflammatory host response ${ }^{9,12-14}$. Some authors have reported $\mathrm{IgG}, \mathrm{IgM}, \operatorname{IgA}, \operatorname{IgE}$ and $\mathrm{IgD}$ antibodies in CSF and/or serum from patients with $\mathrm{NC}$, without correlation between antibody class and clinical aspect of the disease ${ }^{13,15,16}$. In parasitic infections, including the teniasis-cysticercosis complex, the level of total $\operatorname{IgE}$ can be high, many times without the identification of the specificity of the antibody ${ }^{17,18}$.

The objective of the present study was to investigate the humoral immune response in NC by detection of IgG, IgA and IgE antibodies in CSF, serum and saliva samples from patients classified according the evolutionary phase of the disease, by ELISA using T. solium and T. crassiceps antigens.

\section{METHOD}

\section{Samples}

We studied 25 paired samples of CSF, serum and saliva from patients with NC (P), selected according to the General Protocol of Investigation of NC of the Center of Neurological Investigations, University Hospital, Faculty of Medicine of the University of São Paulo. The study was approved by the Ethics Committee for Analysis of Research Projects, Clinical Management of UHFMUSP, 072/97, in agreement with Resolution 196/ 96 of the National Council of Health, Ministry of the Health, Brazil.

The patients were classified as follows on the basis of neuroimaging data (computed tomography and/or nuclear magnetic resonance image): $15(60 \%)$ with the active form (inflammatory process) and $10(40 \%)$ with the inactive form (no inflammatory image, 4 of them with calcified cysts). More detailed: $8 \%$ of the patients with NC presented imaging exams without alterations (type I), $16 \%$ presented intact cysts (type II), $16 \%$ presented degenerating cysts with an inflammatory process (type III), $16 \%$ calcified cysts (type IV), and $44 \%$ more than two evolutionary forms (mixed type) ${ }^{19}$.

As a control group (C) we studied CSF samples from 10 individuals with other neurological disorders, and 35 serum samples and 7 saliva samples from presumably healthy individuals. The group of other parasitoses (OP) consisted of 23 serum samples with immunological tests reactive to other parasitoses, i.e., toxocariasis $(n=7)$, toxoplasmosis $(n=6)$, Chagas' disease $(n=5)$, and schistosomiasis $(n=5)$.

\section{Parasites and antigens}

The parasites, the metacestode forms of $T$. crassiceps (ORF strain) and of T. solium, and the antigenic extracts of vesicular fluid of T. crassiceps (Tcra) and total saline extract of $T$. solium (Tso) were obtained according to Bueno ${ }^{20}$. Phenylmethylsulphonyl fluoride (Sigma Chem. Co., USA), $4 \times 10^{-1} \mathrm{mM}$, was added to each antigenic extract.

\section{Immunoenzymatic test (ELISA)}

Polystirene flat bottom plates were used (Costar Corporation, USA). For blockade we used 5\% skim milk (Nestlé, Brazil) in $0.15 \mathrm{M} \mathrm{NaCl}$ with $0.05 \%$ Tween 20 for 2 hours at $37^{\circ} \mathrm{C}$. We used Tcra and Tso antigens (10 
$\mu \mathrm{g} / \mathrm{ml}$ in 0.05 $\mathrm{M}$ carbonate-bicarbonate buffer, $\mathrm{pH} 9,6$ ), CSF, serum and saliva samples (respectively 1:2, 1:100 and 1:2 in 1\% milk), anti-human IgG-peroxidase conjugate (Biolab Diagnóstica SA, Brazil) and chromogensubstrate $\left(1 \mathrm{~g} / \mathrm{l}\right.$ ortophenylenediamine and $1 \mathrm{ml} / 1 \mathrm{H}_{2} \mathrm{O}_{2}$ in $0.2 \mathrm{M}$ citrate buffer, $\left.\mathrm{pH} 5.0\right)$ in volumes of $100 \mu \mathrm{l} / \mathrm{well}$. The material was incubated at $37^{\circ} \mathrm{C}$ for $1 \mathrm{~h}$, except for the chromogen-substrate, which was incubated for $15 \mathrm{~min}$. The reaction was blocked with $0.5 \mathrm{~N} \mathrm{H}_{2} \mathrm{SO}_{4}$ and the absorbance was read at $492 \mathrm{~nm}$.

For IgA and IgE antibody detection, the samples were pre-treated 1:2 (v/v) with RF-Absorbent (Behring Diagnostic Inc., Germany), previously diluted to 1:2 in distilled water.

The determination of the cut-off for IgG detection in CSF and serum samples was based on the analysis of the diagnostic efficiency of each test according to the Youden index ${ }^{21}$, calculated for values from the $\mathrm{C}$ group [mean + nsd ( $\mathrm{n}-1.16$ to +7.0$)$ ]. The other cut-off rates were defined as the mean of the $\mathrm{C}$ group plus 2 standard deviations.

\section{RESULTS}

The results obtained by ELISA with the Tcra and Tso antigens are presented in the Figure 1.

Table 1. Cut-off, sensitivity and specificity (\%) with respective confidence intervals (CI), and Youden index of ELISA in the detection of $\operatorname{IgG}, \operatorname{IgA}$ and IgE antibodies in CSF, serum and saliva samples using Taenia solium (Tso) and Taenia crassiceps (Tcra) antigens.

\begin{tabular}{|c|c|c|c|c|c|c|c|}
\hline $\begin{array}{l}\mathrm{Ig} \\
\text { Antigen }\end{array}$ & Sample & Cut-off & $\mathrm{n}^{*}$ & $\begin{array}{c}\text { Sensitivity } \\
\text { (CI) }\end{array}$ & $\mathrm{n}^{* *}$ & $\begin{array}{c}\text { Specificity } \\
\text { (CI) }\end{array}$ & $\begin{array}{l}\text { Youden } \\
\text { Index }\end{array}$ \\
\hline \multirow[t]{3}{*}{ IgG Tso } & CSF & 0.078 & 25 & $\begin{array}{c}100.0 \\
(99.4-100.0)\end{array}$ & 10 & $\begin{array}{c}100.0 \\
(99.0-100.0)\end{array}$ & 1.0 \\
\hline & Sera & 0.400 & 25 & $\begin{array}{c}80.0 \\
(72.0-88.0)\end{array}$ & 35 & $\begin{array}{c}80.0 \\
(73.2-86.8)\end{array}$ & 0.600 \\
\hline & Saliva & 0.096 & 25 & $\begin{array}{c}24.0 \\
(15.5-32.5)\end{array}$ & 8 & $\begin{array}{c}87.5 \\
(75.8-99.2)\end{array}$ & 0.115 \\
\hline \multirow[t]{3}{*}{ IgG Tcra } & $\mathrm{CSF}$ & 0.011 & 25 & $\begin{array}{c}100.0 \\
(99.4-100.0)\end{array}$ & 10 & $\begin{array}{c}100.0 \\
(99.0-100.0)\end{array}$ & 1.0 \\
\hline & Sera & 0.097 & 25 & $\begin{array}{c}100.0 \\
(99.4-100.0)\end{array}$ & 35 & $\begin{array}{c}80.0 \\
(73.2-86.8)\end{array}$ & 0.800 \\
\hline & Saliva & 0.172 & 25 & $\begin{array}{c}32.0 \\
(22.7-41.3)\end{array}$ & 9 & $\begin{array}{c}100.0 \\
(99.0-100.0)\end{array}$ & 0.320 \\
\hline \multirow[t]{3}{*}{ IgA Tcra } & $\mathrm{CSF}$ & 0.010 & 25 & $\begin{array}{c}40.0 \\
(30.2-49.8)\end{array}$ & 4 & $\begin{array}{c}100.0 \\
(98.4-100.0)\end{array}$ & 0.400 \\
\hline & Sera & 0.070 & 25 & $\begin{array}{c}36.0 \\
(26.4-45.6)\end{array}$ & 35 & $\begin{array}{c}97.1 \\
(94.3-99.9)\end{array}$ & 0.331 \\
\hline & Saliva & 0.106 & 25 & $\begin{array}{c}4.0 \\
(0.1-7.9)\end{array}$ & 10 & $\begin{array}{c}90 \\
(80.5-99.5)\end{array}$ & 0 \\
\hline \multirow[t]{2}{*}{ IgE Tcra } & $\mathrm{CSF}$ & 0.252 & 25 & 0 & 4 & $\begin{array}{c}100.0 \\
(98.4-100.0)\end{array}$ & 0 \\
\hline & Sera & 0.135 & 25 & $\begin{array}{c}24.0 \\
(15.5-32.5)\end{array}$ & 35 & $\begin{array}{c}97.1 \\
(94.3-99.9)\end{array}$ & 0.211 \\
\hline
\end{tabular}

*patient with $\mathrm{NC}$; ** control group 


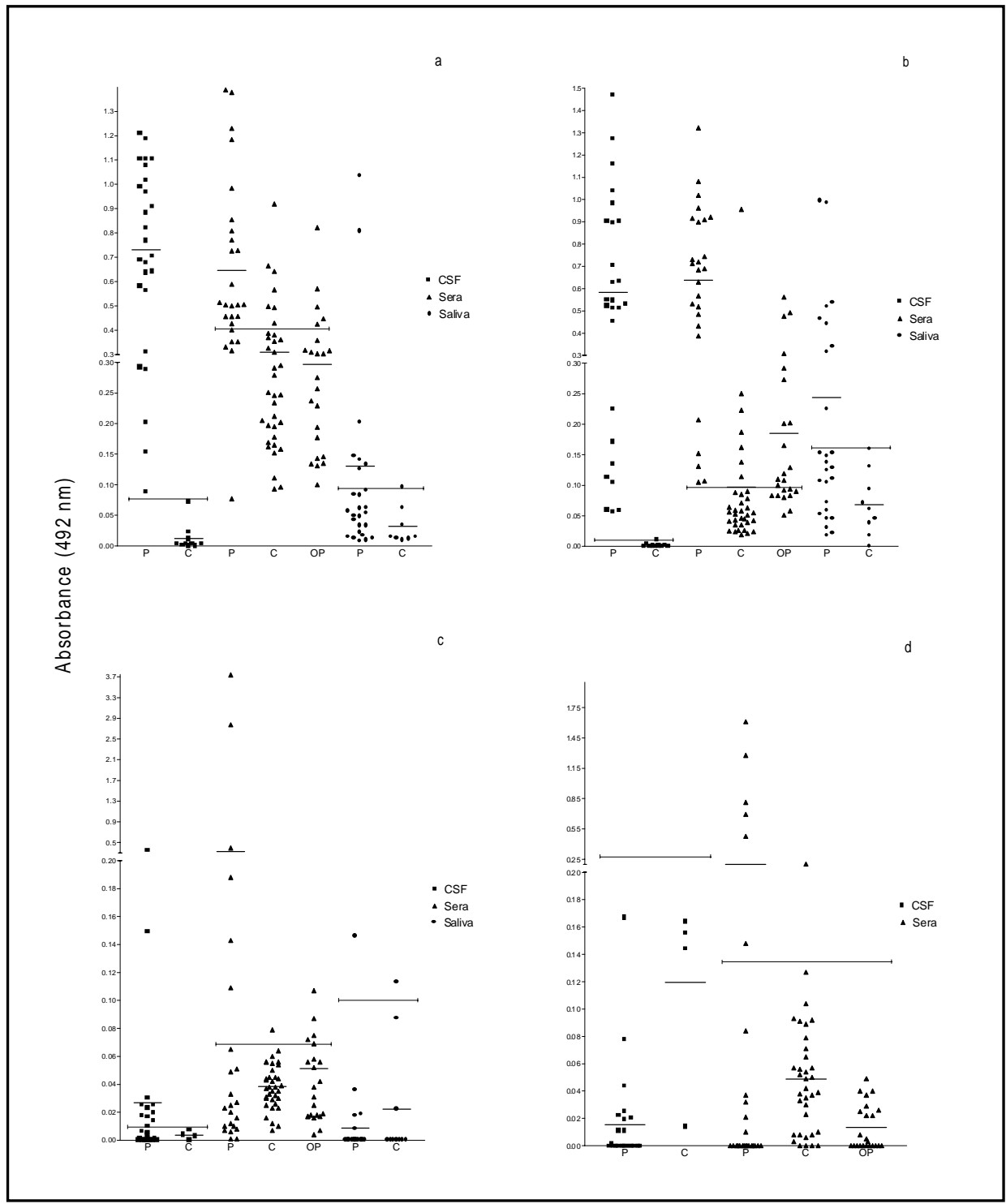

Fig 1. Results of CSF, sera and saliva samples from patients with neurocysticercosis $(P)$, control group $(C)$ and a group with other parasitosis (OP) obtained by ELISA using the total saline antigen of Taenia solium (a) and vesicular fluid antigen of Taenia crassiceps $(b, c, d)$ for the detection of $\operatorname{Ig} G(a, b), \operatorname{IgA}(c)$ and $\operatorname{IgE}(d)$ antibodies |-|: cut-off.

Table 1 presents the indexes of the tests: cut-off, sensitivity and specificity, confidence intervals (95\% probability), and Youden index.

In the OP group $5(22 \%)$ samples were IgG-reactive with Tso antigen (toxoplasmosis, toxocariasis and schistosomiasiss) and more $9(39 \%)$ other samples reacted with Tcra (plus Chagas' disease). IgA antibodies were detected in 5 (22\%) serum samples (toxocariasis, Chagas' disease and schistosomiasis). 
Statistical analysis of the results by the Mann-Whitney test revealed a significant difference between the $\mathrm{P}$ group and the C/OP groups for IgG and IgE detection in CSF and serum samples (p $<0.0389$ ). IgA detection did not show a significant difference between the $\mathrm{P}$ and $\mathrm{C}$ groups ( $\mathrm{p}>0.5425)$. The saliva samples showed a significant difference between the $\mathrm{P}$ and $\mathrm{C}$ groups only for $\mathrm{IgG}$ in the ELISA Tcra $(\mathrm{p}=0.0330)$.

\section{DISCUSSION}

The biological parasite-host interactions involved in $\mathrm{NC}$ are complex because of the different evolutionary stages of the parasite and of the individual variations of the response of the host ${ }^{6}$. On the other hand, it is difficult to obtain appropriate antigens in sufficient amounts for the immunological tests from swine naturally infected with Taenia solium metacestode, of clandestine creation. The model of murine cysticercosis induced by Taenia crassiceps, of easy maintenance in the laboratory, appears as an alternative for obtaining parasites due to the antigens shared by Taenia species ${ }^{2,7-11}$.

The classification of NC patients in the present study ${ }^{22}$ showed that only $60 \%$ had the active form of the disease, or cysts in degeneration and immune-inflammatory processes. Although $40 \%$ of the patients had the inactive form of the disease, the $\operatorname{IgG}$ detection showed sensitivity of $100.0 \%$ for CSF and serum and $32.0 \%$ for saliva with Tcra antigen, and $100.0 \%$ for CSF, $80.0 \%$ for serum and $24.0 \%$ for saliva with Tso antigen

Similar results were related by VAZ, $1993^{23}$, in ELISA with $T$. solium total antigen and $T$. crassiceps vesicular fluid antigen of LCR samples from patients with NC. Less sensitive results were obtained by other authors using T. crassiceps vesicular fluid antigen and $\mathrm{CSF}^{2,7}$ or $T$. solium total antigen and serum ${ }^{13}$. Kunz et al. ${ }^{24}$, detected antibodies in the 14 serum samples analyzed by ELISA with antigen of vesicular fluid from T. cracisseps and T. solium, with higher reading intensity with $T$. solium antigen, similar to our results (Fig 1). Otherwise, other authors reported higher sensitivity than us for IgG detection in saliva samples ${ }^{25,26}$.

The IgA detection with Tcra antigen revealed sensitivity and specificity, of $40.0 \%$ and $100.0 \%$ for CSF, $36.0 \%$ and $97.1 \%$ for serum, and $4.0 \%$ and $90.0 \%$ for saliva, respectively, while the IgE detection showed sensitivity of $24.0 \%$ and specificity of $97.1 \%$ for serum, and no CSF sample was reactive. Different results were reported by other authors, like Espinoza et al. ${ }^{13}$ using ELISA with $T$. solium total antigen for IgA detection, with positivity of $25 \%$ for serum and of $13 \%$ for CSF, and $3 \%$ positivity for IgE in serum and CSF. These discordant results reinforce the heterogeneity of the humoral immune response involved in the parasite-host interaction in NC. Acosta ${ }^{26}$ did not find any difference in IgA detection in saliva samples between the group of patients with NC, the control group and the group with other neurological disorders by ELISA with T. solium total antigen. Although we used the Tcra antigen, we also did not find significant differences among the groups in CSF, serum or saliva samples $(\mathrm{p}<0.001)$.

Five serum samples from patients with $\mathrm{NC}$ were negative for $\mathrm{IgG}$ detection with Tso antigen, but positive for Tcra. Two (40\%) of them presented cysts in degeneration, 2 (40\%) calcified cysts, and $1(20 \%)$ a normal imaging exam. These results suggest a higher sensitivity of the Tcra antigen in the detection of serum antibodies in patients that do not present signs of inflammatory processes. Some authors have reported lower sensitivity of the immunological tests in patients with calcified cysts, independent of the antigen employed ${ }^{24,27,28}$.

The IgA detection showed positivity in serum samples of 33\% patients with the active form and in $40 \%$ patients with the inactive form, while $\operatorname{IgE}$ was detected in $20 \%$ and $30 \%$ of cases, respectively. The IgA and IgE detection in the serum samples showed higher positivity in patients with the inactive form, and these results can be justified by liberation of antigenic products during the death and degeneration of the parasite, with formation of antigen-antibodies immune complexes in patients in active form ${ }^{29}$. Differently, other authors did not obtain a correlation between the antibody class and the clinical aspect of the disease ${ }^{13,15,16}$. 
The frequency of specific antibodies detected by ELISA, independently of the sample, presented immunoglobulins of the G, A and E classes, in this order of frequency, similar to those found by other authors ${ }^{13}$. However, other authors identified immunoglobulins of the G, M, E, A and $\mathrm{D}$ classes, in this order of frequency, in serum samples ${ }^{16,30}$. The presence of anti- $T$. solium IgG antibodies at a higher frequency in CSF samples than in serum and in saliva samples is indicative of a secondary immune response, and is justified by the chronic process of the disease ${ }^{13}$, and also by the presence of the antibodies, except for $\mathrm{IgG}$, on the surface of the parasite and consequently absent as circulating antibodies ${ }^{15}$. However, some authors have suggested that the $\operatorname{IgM}, \operatorname{IgA}$ and $\operatorname{IgE}$ antibodies are not important in the $\mathrm{NC}$ immune response ${ }^{12,17}$.

The specific antibodies of the $\operatorname{IgG}$ and $\mathrm{IgA}$ classes in patients with $\mathrm{NC}$ were more frequent in CSF, followed by serum and then by saliva. Only the specific antibody of the IgE class was more frequent in serum than in CSF. Acosta ${ }^{26}$, had already reported that there was no significant difference between the results obtained with serum and saliva samples for IgG detection by ELISA with $T$. solium total antigen, with a better performance for CSF samples. The higher frequency of antibodies in CSF is expected due to the local immune response at the site of lesion and to the compartmentalization of the process.

The results obtained with the Tcra and Tso antigens reinforce that the parasites share important antigenic determinants and in enough concentrations for use in the immunodiagnosis of NC, using CSF and serum samples for IgG detection, although confirmation of positive results is needed for serum samples because of the lower specificity. The Tcra antigen presented better efficiency and more homogeneous results in the detection of serum-specific antibodies, especially in the presence of calcifications and of a reduced immune-inflammatory response. We believe that the Tcra antigen, although heterologous, presents these advantages by being rich in components of vesicular fluid that probably involve soluble antigens of secretion and excretion. These antigens are also present in T. solium cysticerci, but at lower concentrations than in the membrane components and scolex, due to the disruption of the vesicles in the process of obtaining parasite.

The search for antibodies in patients with $\mathrm{NC}$ revealed the presence of immunoglobulins of the $\mathrm{G}>\mathrm{A}>\mathrm{E}$ classes in CSF, serum and saliva samples, in this order of frequency. We also observed the presence of $\operatorname{IgG}$ in all different evolutionary phases of the disease, while antibodies of the IgA and $\operatorname{IgE}$ classes were more frequent in the patients with the inactive form, with no degenerating cysts or immune-inflammatory processes, demonstrating the heterogeneity of the humoral immune response to NC. The study of these immunoglobulins in a larger number of samples from patients with NC in different clinical phases may be helpful for a better understanding of the parasite-host relationship.

Acknowledgements - We wish to thank Dr. Antônio Walter Ferreira and Hermínia Y. Kanamura for providing some samples, Biolab-Meuriex for the conjugate used in ELISA, Dra. Vitória Bastouly for her help in collecting CSF, and Paulo M. Nakamura for technical support.

\section{REFERENCES}

1. Shasha W, Pammenter MD. Sero-epidemiological studies of cysticercosis in school children from two rural areas of Transkei, South Africa. Ann Trop Med Parasitol 1991;85:349-355.

2. Garcia E, Ordonez G, Sotelo J. Antigens from Taenia crassiceps used in complement fixation, enzyme-linked immunosorbent assay, and western blot (immunoblot) for diagnosis of neurocysticercosis. J Clin Microbiol 1995;33:3324-3325.

3. Agapejev S. Epidemiology of neurocysticercosis in Brazil. Rev Inst Med Trop São Paulo 1996;38:207-216.

4. Sarti E, Flisser A, Schantz PM, et al. Development and evaluation of a health education intervention against Taenia solium in a rural community in Mexico. Am J Trop Med Hyg 1997;56:127-132.

5. Singh G. Neurocysticercosis in South-Central America and the indian subcontinent. Arq Neuropsiquiatr 1997;55:349-356.

6. Schantz PM, Moore AC, Muñoz JL, et al. Neurocysticercosis in an orthodox jewish community in New York City. N Engl J Med 1992;327:692-695.

7. Larralde C, Sotelo J, Montoya RM, et al. Immunodiagnosis of human cysticercosis in cerebrospinal fluid. Arch Pathol Lab Med 1990;114:926-928.

8. Andrade AP, Vaz AJ, Nakamura PM, Palou VSEB, Cunha RAF, Ferreira AW. Immunoperoxidase for the detection of antibodies in cerebrospinal fluid in neurocysticercosis: use of Cysticercus cellulosae and Cysticercus longicollis particles fixed on microscopy slides. Rev Inst Med Trop São Paulo 1996;38: 259-263. 
9. Ferreira AP, Vaz AJ, Nakamura PM, Sasaki AT, Ferreira AW, Livramento JA. Hemagglutination test for the diagnosis of human neurocysticercosis: development of a stable reagent using homologous and heterologous antigens. Rev Inst Med Trop São Paulo 1997;39:29-33.

10. Vaz AJ, Nunes CM, Piazza RMF, et al. Immunoblot with cerebrospinal fluid from patients with neurocysticercosis using antigen from cysticerci of Taenia solium and Taenia crassiceps. Am J Trop Med Hyg 1997;57:354-357.

11. Vaz AJ, Nakamura PM, Barreto CC, Ferreira AW, Livramento JA, Machado ABB. Immunodiagnosis of human neurocysticercosis: use of heterologous antigenic particles (Cysticercus longicollis) in indirect immunofluorescence test. Serodiagnosis Immunotherapy Infectious Diseases 1997;8:157-161.

12. Estanol B, Guárez H, Irigoyen MC, González-Barranco D, Corona T. Humoral immune response in patients with cerebral parenchymal cysticercosis treated with praziquantel. J Neurol Neurosurg Psyquiatry 1989;52:254-257.

13. Espinoza B, Palacios GR, Tovar A, Sandoval MA, Plancarte A, Flisser A. Characterization by ELISA of the humoral immune response in patients with neurocysticercosis and its application in immunodiagnosis. J Clin Microbiol 1986;24:536-541.

14. Bonametti AM, Basile MA, Vaz AJ, Baldy JLS, Takiguti CK. Índice de positividade da reação imunoenzimática (ELISA) para cisticercose no líquido cefalorraquidiano (LCR) e no soro de pacientes com epilepsia. Rev Inst Med Trop São Paulo. 1992;34:451-458.

15. Correa D, Dalma D, Espinoza B, et al. Heterogeneity of humoral immune components in human cysticercosis. J Parasitol 1985;71:535-541.

16. Grogl M, Estrada JJ, Macdonald G, Kuhn RE. Antigen-antibody analysis in neurocysticercosis. J Parasitol 1985;71:433-442.

17. Short JA, Heiner DC, Hsiao RL, Andersen FL. Immunoglobulin E and G4 antibodies in cysticercosis. J Clin Microbiol 1990;28:1635-1639.

18. Melo CS, Vaz AJ, Nakamura PM, Silva MV, Machado ABB. Human neurocysticercosis. IgE in cerebrospinal fluid. Arq Neuropsiquiatr 1997;55:8-11

19. Machado LR, Nobrega JPS, Barros NG, Livramento JA, Bacheschi LA, Spina-França A. Computed tomography in neurocysticercosis. A 10 year long evolution analysis of 100 patients with an appraisal of a new classification. Arq Neuropsiquiatr 1990;48:414-418.

20. Bueno EC. Neurocisticercose: avaliação da resposta imune humoral nas diferentes fases evolutivas da doença pelo ELISA e imunoblot com antígenos de T. solium e T. crassiceps. São Paulo: Tese, Faculdade de Ciências Farmacêuticas da Universidade de São Paulo, São Paulo, 1999.

21. Youden D. Index for rating diagnostic test. Cancer 1950;3:32-35.

22. Sotelo J, Guerrero V, Rubio F. Neurocysticercosis: a new classification based on active and inactive forms. Arch Intern Med 1985;145:442-445.

23. Vaz AJ. Cysticercus longicollis: caracterização antigênica e desenvolvimento de testes imunológicos para pesquisa de anticorpos em líquido cefalorraquiano no imunodiagnóstico da neurocisticercose humana. São Paulo: Tese, Instituto de Ciências Biomédicas da Universidade de São Paulo, São Paulo, 1993.

24. Kunz J, Kalinna B, Watschke V, Geyer E. Taenia crassiceps metacestode vesicular fluid antigens shared with the Taenia solium larval stage and reactive with serum antibodies from patients with neurocysticercosis. Zbl Bakt 1989;271:510-520.

25. Feldman M, Plancarte A, Sandoval M, Wilson M, Flisser A. Comparison of two assays (EIA and EITB) and two samples (saliva and serum) for the diagnosis of neurocysticercosis. Trans R Soc Trop Med Hyg 1990;84:559-562.

26. Acosta E. Antibodies to the metacestode of Taenia solium in the saliva from patients with neurocysticercosis. J Clin Lab Anal 1990;4:90-94.

27. Michault A, Rivière B, Fressy P, Laporte Jp, Bertil G, Mignard C. Apport de l'enzyme-linked immunoeletrotransfer blot assay au diagnostic de la neurocysticercose humaine. Path Biol 1990;38:119-125.

28. Wilson M, Bryan RT, Fried JA, et al. Clinical evaluation of the cysticercosis enzyme-linked immunoelectrotransfer blot in patients with neurocysticercosis. J Infect Dis 1991;164:1007-1009.

29. Letonja T, Hammerberg C, Schurig G. Evaluation of spleen lymphocyte responsiveness to a T-cell mitogen during early infection with larval Taenia taeniaeformis. Parasitol Res 1987;73:265-270.

30. Flisser A, Woodhouse E, Larralde C. Human cysticercosis: antigens, antibodies and non-responders. Exp Immunol 1980;39:27-37. 